\title{
Plant Disease Diagnosis Expert System Cardamom (Ammomum Cardamomum I.) Using The Naive Bayes Method Web-Based
}

\author{
Calvin Berkat Iman Hulu', Hengki Tamando Sihotang ${ }^{2}$ \\ ${ }^{1,2}$ Informatics Engineering, STMIK Pelita Nusantara, Sumatera Utara, Indonesia
}

\begin{tabular}{|c|c|}
\hline ARTICLE INFO & ABSTRACT \\
\hline Article history: & \multirow{4}{*}{$\begin{array}{l}\text { Diseases and pests on cardamom plants is one of the diseases and } \\
\text { pests that can seriously attack cardamom plants. Cardamom plant } \\
\text { diseases and pests can be diagnosed through the symptoms that } \\
\text { are currently being experienced by the cardamom or through its } \\
\text { clinical picture, through these symptoms an expert system can be } \\
\text { made to make a diagnosis. An expert system is a system that seeks } \\
\text { to adopt human knowledge to a computer that is built to solve } \\
\text { problems like an expert. The expert system made in carrying out the } \\
\text { diagnosis uses the Naïve Bayes method. This method is a simple } \\
\text { probabilistic-based prediction technique based on the application of } \\
\text { Bayes' rules with the assumption of strong (naive) independence. In } \\
\text { other words, in Naïve Bayes the model used is an "independent } \\
\text { feature model". This expert system was built using PHP and MySQL } \\
\text { programming as a database. In this expert system the types of } \\
\text { cardamom disease diagnosed consisted of aphids, leaf-eating } \\
\text { caterpillars, stem borers, fruit and roots, leaf beetles, mosaics, late } \\
\text { blight, root rot, and fungus, which consisted of } 33 \text { symptoms. While } \\
\text { the results of the diagnosis will inform about the results of the } \\
\text { diagnosis containing a list of symptoms entered, information on the } \\
\text { results of regulations regarding diseases and pests that are } \\
\text { attacking cardamom plants and information about possible } \\
\text { treatments that can be carried out and treatment solutions. }\end{array}$} \\
\hline $\begin{array}{r}\text { Received Nov 9, } 2021 \\
\text { Revised Nov 20, } 2021 \\
\text { Accepted Des 08, } 2021\end{array}$ & \\
\hline & \\
\hline $\begin{array}{r}\text { Cardamom Diseases and Pests; } \\
\text { Naive Bayes; } \\
\text { Expert System. }\end{array}$ & \\
\hline
\end{tabular}

This is an open access article under the CC BY-NC license.

\section{Corresponding Author:}

Calvin Berkat Iman hulu, Informatics Engineering,

STMIK Pelita Nusantara, Sumatera Utara, Indonesia

J. Iskandar Muda No.1 Medan, Sumatera Utara, Indonesia

Email: calvinhulu1999@gmail.com

\section{INTRODUCTION}

Technological advances that continue to develop have changed the form of data processing in various forms of human effort from manual systems to computerized systems. It can be seen that most of the people who depend on technology in their daily work depend on technology. The current era of technology has a fairly broad impact on various aspects of human life, including in agriculture, one of which is to help farmers, especially cardamom farmers, to diagnose diseases and pests that attack their plants. Cardamom is one of the many spices needed by the community as a cooking ingredient, herbal medicine to pharmacy (Yudhani et al., 2019) (Awasthi \& Pandey, 2016). 
Cardamom is a shrub that grows well, which requires fertile, loose and well-drained soil. Soil like this is abundant in Indonesia at various altitudes below 1,000 meters above sea level (asl), rainfall is $2000-4000 \mathrm{~mm}$ per year. The selling price of dried cardamom per kilogram is between Rp. 90,000 to Rp. 110. 000. (Park, n.d.) However, in farming cardamom, farmers often experience losses and crop failure due to the many pests and diseases that attack the plant. including aphids, leaf-eating caterpillars, stem borers, fruit and roots, leaf beetles, root rot, etc. Most cardamom plant farmers do not know about diseases and pests that have attacked plants, due to the lack of experts or agricultural extension workers who help farmers in providing solutions to diseased plants (Nair, 2007).

The method used to diagnose disease in cardamom plants is nave bayes (Vassallo-Barco et al., 2017). This method is a simple probabilistic-based prediction technique based on the application of Bayes' theorem (Bayes rule) with the assumption of strong (naive) independence. In other words, in Naïve Bayes the model used is an "independent feature model" (Sinaga \& Suwilo, 2020)(Syafira et al., 2020) (Suada et al., 2016). The nave Bayes method is applied to describe the level of confidence of an expert on the problem (Choy et al., 2009). Development or design of an expert system application for the diagnosis of diseases and pests on plants (Sarma et al., 2010). Cardamom is one of the applications of a computerized system in agriculture (Jose \& Krishnan, 2015)(Adhikari \& Sobin, 2021). Using the nave bayes method as a method in this research, because when faced with a problem in diagnosing diseases and pests on cardamom plants, answers are often found that do not have full certainty and even the answers are doubtful. To accommodate this, what is being faced with uncertainty and doubt answers in the form of probability values that depend on the results of the diagnosis event, namely by counting the number of classes/labels, counting the number of cases per class, then multiplying all the variables in the class and then comparing the results per class to display the diagnostic results (Simões, 2021). The nave Bayes method has the advantage that it is easy to implement and gives good results for many cases, while the disadvantage is that it must assume that between features are not related (independent) in reality, the relationship cannot be modeled by nave Bayes (Syarief et al., 2017). Expert system is a field in artificial intelligence (Artificial Intelligent) that is used for decision making by an expert using knowledge, facts and thinking techniques in solving problems that are usually solved by an expert concerned (Setiawan et al., 2018).

\section{METHOD}

The research framework is a number of steps or thoughts, concepts, ideas, or assumptions that are used to organize the thought process about something or a situation.

\section{a. Data collection}

Data collection is the next stage in conducting observations, interviews, and documentation.

b. Study of literature

The literature study in question is looking for theoretical references that are relevant to the case or problem found in accordance with the research title. These references are obtained from books, journals, research report articles, printed books and electronic books. The output of this literature study is the collection of references relevant to the formulation of the problem, the aim is to strengthen the problem and as a theoretical basis in conducting studies and also to become the basis for conducting control designs and flow simulations in building an expert system application for diagnosing cardamom plant diseases using the nave Bayes method.

c. Data analysis

Data analysis aims to find accurate and reliable information so that the data is useful. From the data obtained, it will be found several types of cardamom plant diseases, symptoms of the disease and treatment solutions.

d. Application of the Naïve Bayes method 
After data collection and data have been collected, the next step is to analyze or process the previously collected data using the nave Bayes method with the aim that the problem formulation can be resolved so that the expert system for diagnosing diseases and pests on cardamom plants can be useful.

e. System Design and System Creation

System design is the stage after the data analysis process is carried out using the nave Bayes method. This system design aims to describe the system that will be built later.

f. System testing is to test the functionality of all systems and error handling on the system made whether it is as expected. Testing of this system will be first carried out on the localhost server, for example: http://localhost/diagnosa-disease-cardamom/.

g. System Implementation

Implementation is the final activity of the process of implementing a new system where this stage is the stage of putting the system so that it is ready for operation and can be seen as an effort to realize the system that has been designed. The steps in this implementation phase are the sequence of activities from start to finish that must be carried out in realizing the system that has been designed.

\section{RESULTS AND DISCUSSIONS}

System requirements analysis is an important stage in building a system and to make it easier to analyze the system.

a. Disease Data

TABLE 1.

DISEASE DATA

\begin{tabular}{cclc}
\hline Num & Code & Disease Name & Attack Percentage \\
\hline 1 & P1 & Aphids & $95 \%$ \\
2 & P2 & Leaf-eating caterpilar & $85 \%$ \\
3 & P3 & Stem, Fruit and Root Borers & $95 \%$ \\
4 & P4 & Leaf beetle & $65 \%$ \\
5 & P5 & Mosaic & $70 \%$ \\
6 & P6 & Rotten Leaves & $85 \%$ \\
7 & P7 & Root Rot & $90 \%$ \\
8 & P8 & Fugus & $75 \%$ \\
\hline
\end{tabular}

b. Symptom Data

TABLE 2.

SYMPTOM

\begin{tabular}{cclc}
\hline Num & $\begin{array}{c}\text { Alternate } \\
\text { Code }\end{array}$ & \multicolumn{1}{c}{ Sympton } & Attack Percentage \\
\hline 1 & G01 & $\begin{array}{l}\text { Leaves and leaf shoots become wrinkled, thin and the leaf } \\
\text { shoots shrivel up }\end{array}$ & $95 \%$ \\
2 & G02 & The leaves are starting to wither and turn yellow & $85 \%$ \\
3 & G03 & The leaves and stems are weak & $83 \%$ \\
4 & G04 & Plant growth is stunted & $80 \%$ \\
5 & G05 & No new leaves grow & $75 \%$ \\
6 & G06 & There are holes in the leaves & $100 \%$ \\
7 & G07 & Grouping plant leaves & $90 \%$ \\
8 & G08 & There is caterpillar droppings on the surface of the leaves or & $85 \%$ \\
9 & G09 & stems & $70 \%$ \\
10 & G010 & Plants are starting to wither & $60 \%$ \\
\hline
\end{tabular}


c. Knowledge Base

TABLE 3.

\begin{tabular}{cll}
\multicolumn{2}{c}{ KNOWLEDGE BASE (RULE) } \\
\hline Num & \multicolumn{1}{c}{ THEN } \\
\hline 1 & G01, G02, G03, G04, G05 & Aphids \\
2 & G02, G06, G07, G08, G09, G10 & Leaf-eating caterpilar \\
3 & G02, G03, G11, G12, G13, G14, G15, G16 & Stem, Fruit and Root Borers \\
4 & G05, G09, G10, G17, G18 & Leaf beetle \\
5 & G01, G02, G17, G19, G20, G21 & Mosaic \\
6 & G03, G04, G05, G10, G18, G22, G23, G24, G25 & Rotten Leaves \\
7 & G13, G15, G17, G26, G27, G28 & Root Rot \\
8 & G15, G18, G19, G23, G29, G30, G31, G32, G33 & Fugus \\
\hline
\end{tabular}

d. Case Study Calculation of the Naïve Bayes Method

The following is a case study of manual calculations from one of the tests by the user by inputting some of the symptoms of the disease being experienced by cardamom plants belonging to the farmer (user), namely:

1. Symptoms $(\mathrm{G} 01)=$ Leaves and shoots become wrinkled, thin and leaf shoots frown.

2. Symptoms $(\mathrm{G} 03)=$ Leaves and stems are weak.

3. Symptoms $(\mathrm{G} 05)=$ No new leaves growing .

4. Symptoms $(\mathrm{G} 08)=$ There is caterpillar droppings on the surface of the leaves or stems.

5. Symptoms $(\mathrm{G} 10)=$ Plants begin to wither.

6. Symptoms $(\mathrm{G} 17)=$ There are few damaged leaves and only primary leaf bone only.

7. Symptoms $(\mathrm{G} 18)=$ Leaves begin to rot and cause plant death .

TABLE 4.

CASE STUDY

\begin{tabular}{rccc}
\hline CSymptom & Choice & Symptom & Choice \\
\hline G01 & Yes & G18 & Yes \\
G02 & No & G19 & No \\
G03 & Yes & G20 & No \\
G04 & No & G21 & No \\
G05 & Yes & G22 & No \\
G06 & No & G23 & No \\
G07 & No & G24 & No \\
G08 & Yes & G25 & No \\
G09 & No & G26 & No \\
G10 & Yes & G27 & No \\
G11 & No & G28 & No \\
G12 & No & G29 & No \\
G13 & No & G30 & No \\
G14 & No & G31 & \\
G15 & No & G32 & G33 \\
G16 & No & & \\
G17 & Yes & &
\end{tabular}

Based on the type of evidence or symptoms of diseases and pests inputted by the user more than one evidence or symptom, the probability value of each disease is known: 
1. $\mathrm{P}(\mathrm{Hi})$ For Aphid Disease, Probability $=0.95$

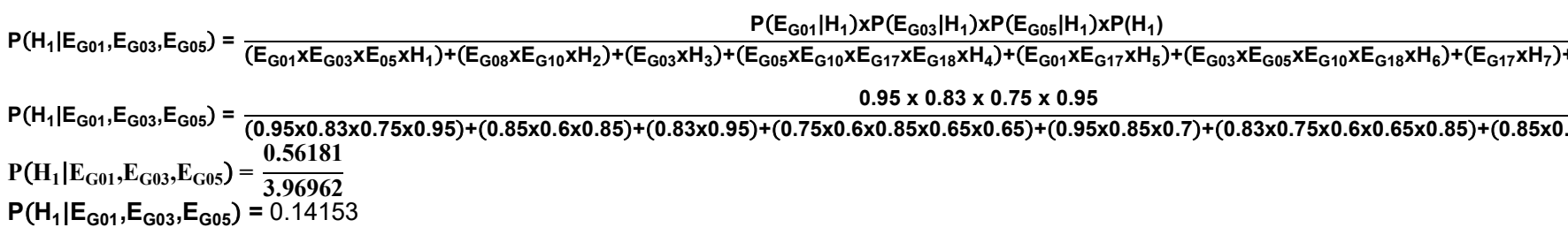

2. $\mathrm{P}(\mathrm{Hi})$ For Leaf-eating Caterpillar Disease, Probability $=0.85$

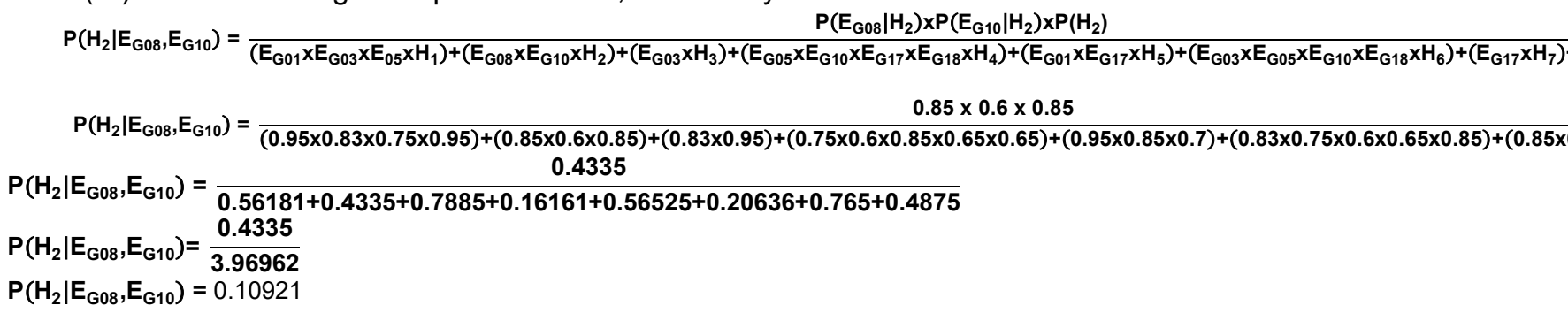

Likewise with the next calculation until $\mathrm{P}(\mathrm{Hi})$ For Fungal Disease, Probability $=0.75$

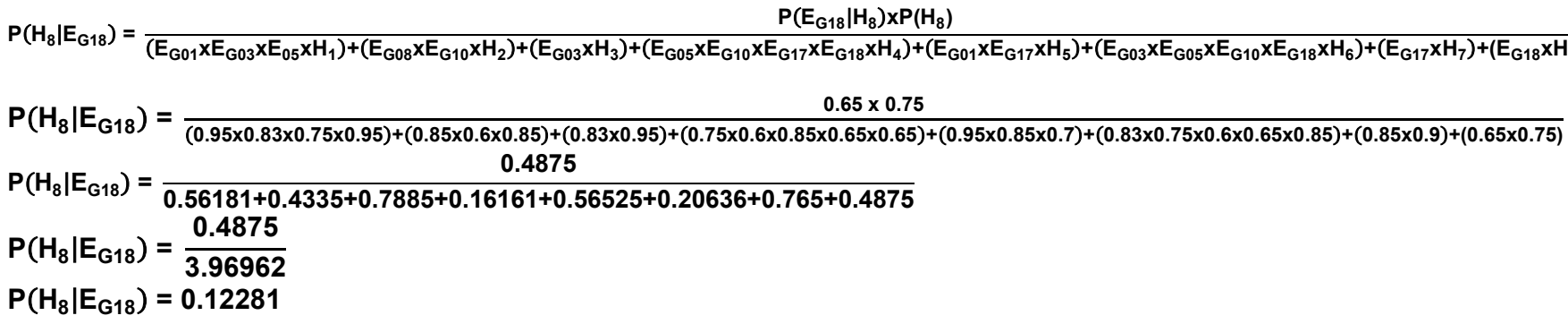

From the results of the above calculation, the result of $v$ which has the largest multiplication can be seen in the following table:

TABLE 5.

TABle Comparison Of VALUe V Classification Rusults

\begin{tabular}{ccll}
\hline Num & Code & Disease Name & V value \\
\hline 1 & P1 & Aphids & $0.14153 \%$ \\
2 & P2 & Leaf-eating caterpilar & $0.10921 \%$ \\
3 & P3 & Stem, Fruit and Root Borers & $0.19864 \%$ \\
4 & P4 & Leaf beetle & $0.04071 \%$ \\
5 & P5 & Mosaic & $0.14240 \%$ \\
6 & P6 & Rotten Leaves & $0.05199 \%$ \\
7 & P7 & Root Rot & $0.19272 \%$ \\
8 & P8 & Fugus & $0.12281 \%$ \\
\multicolumn{7}{l}{ The highest score } & $0.19864 \%$ \\
\hline
\end{tabular}

It is known that the highest value $(v)$ with a value of $0.19864 \%$, so it can be classified that the user's cardamom is attacked by diseases and pests P3 $=$ Stem, Fruit and Root Borers.

\section{CONCLUSION}

After completing the design of an expert system application to diagnose eye diseases due to frequent use of computers using the Bayes theorem method, there are several things that can be concluded, namely the application of the Naive Bayes method to diagnose diseases and pests on 
cardamom plants, namely by collecting sample data in research such as disease data and pests that attack cardamom plants as well as symptom data and rules (rule) or disease knowledge base, an expert system for diagnosing cardamom plant diseases (Ammomum Cardamomum L.) using the web-based nave Bayes method was designed using Unified Modeling Language (UML) modeling by using Use Case diagrams, Activity Diagrams and Class Diagrams and built using the PHP programming language with MySQL database. The results obtained from the diagnosis of diseases and pests on cardamom plants with the application of an expert system using the Naive Bayes method, namely determining the symptoms experienced by the patient, for example: the leaves begin to wilt and turn yellow, the leaves and stems begin to weaken. Based on the process of calculating the probability value of symptoms for disease using the naive bayes method, it shows accurate diagnosis of diseases and pests so that by applying the nave bayes method, the expert system built is very suitable to be used to diagnose diseases and pests on cardamom plants.

\section{References}

Adhikari, B., \& Sobin, C. C. (2021). Building Market Intelligence Systems for Agricultural Commodities: A Case Study based on Cardamom. 2021 2nd International Conference on Secure Cyber Computing and Communications (ICSCCC), 12-16.

Awasthi, K. K., \& Pandey, A. (2016). Utilization of Traditional Herbs, Spices, Seasoning and Condiments: A Case Study of the Preparation of "Buknu" in Selected Villages of Kanpur, Uttar Pradesh, India. European Journal of Medicinal Plants, 1-11.

Choy, S. L., O'Leary, R., \& Mengersen, K. (2009). Elicitation by design in ecology: using expert opinion to inform priors for Bayesian statistical models. Ecology, 90(1), 265-277.

Jose, R. M., \& Krishnan, K. S. S. (2015). Cardamom grading-A solution through machine learning techniques. 2015 Global Conference on Communication Technologies (GCCT), 303-306.

Nair, K. S. S. (2007). Tropical forest insect pests: ecology, impact, and management. Cambridge University Press.

Park, E. K. (n.d.). Exploring the Innovation in Agriculture of Developing Country.

Sarma, S. K., Singh, K. R., \& Singh, A. (2010). An Expert System for diagnosis of diseases in Rice Plant. International Journal of Artificial Intelligence, 1(1), 26-31.

Setiawan, A., Hidayat, N., \& Dewi, R. K. (2018). Sistem Pakar Diagnosis Penyakit Tanaman Cengkeh Menggunakan Metode Naive Bayes (Studi Kasus Kecamatan Wonosalam, Jombang). Jurnal Pengembangan Teknologi Informasi Dan Ilmu Komputer E-ISSN, 2548, 964X.

Simões, M. S. R. M. (2021). Automatic Breast Density Classification on Tomosynthesis Images.

Sinaga, L. M., \& Suwilo, S. (2020). Analysis of classification and Naïve Bayes algorithm k-nearest neighbor in data mining. IOP Conference Series: Materials Science and Engineering, 725(1), 12106.

Suada, L., Wijaya, I. D., \& Rohadi, E. (2016). Sistem pakar identifikasi hama dan penyakit tanaman tebu menggunakan metode naïve bayes. Seminar Informatika Aplikatif Polinema.

Syafira, D., Suwilo, S., \& Sihombing, P. (2020). Analysis of attribute reduction effectiveness on the naive Bayes classifier method. Journal of Physics: Conference Series, 1566(1), 12060.

Syarief, M., Mukminin, A., Prastiti, N., \& Setiawan, W. (2017). PENERAPAN METOdE NAÏVE BAYES CLASSIFIER UNTUK. Jurnal IImiah NERO, 3(1), 61-68.

Vassallo-Barco, M., Vives-Garnique, L., Tuesta-Monteza, V., Mejía-Cabrera, H. I., \& Toledo, R. Y. (2017). Automatic Detection of Nutritional Deficiencies In Coffee Tree Leaves Through Shape And Texture Descriptors. Journal of Digital Information Management, 15(1).

Yudhani, R. D., Pesik, R. N., Azzahro, S., Anisa, A. F., \& Hendriyani, R. (2019). Renal Function Parameter on Acute Toxicity Test of Kapulaga (Amomum cardamom) Seed Extract in Rat. IOP Conference Series: Materials Science and Engineering, 578(1), 12053. 